\title{
KNOWLEDGE-BASED COLLABORATIVE LEAN MANUFACTURING MANAGEMENT (KBCLMM) SYSTEM
}

\author{
SYSTEM ZESPOLOWEGO ZARZĄDZANIA \\ PRODUKCJĄ, OBNIŻAJĄCY NAKLADY, OPARTY \\ NA BAZIE WIEDZY
}

\author{
Mohd Kamal Mohd Nawawi', Mohammed Khurshid Khan ${ }^{2}$, \\ Khalid Hussain ${ }^{3}$
}

\author{
$(1,2,3)$ School of Engineering, Design and Technology, University of Bradford, \\ Bradford BD7 1DP, United Kingdom \\ E-mails: (1)mkbmohdn@bradford.ac.uk (2)m.k.khan@bradford.ac.uk (3) \\ k.hussain1@bradford.ac.uk
}

\begin{abstract}
The objective of this research paper is to demonstrate the application of hybrid Knowledge-Based System, Gauging Absences of Pre-Requisites (GAP), and Analytic Hierarchy Process (AHP) approaches for selecting the improvement programs for Collaborative Lean Manufacturing Management (CLMM) System. In this research, a generic Knowledge-Based System is developed to measure the level of CLMM adoption in automotive manufacturers compared to the ideal system. Using the embedded GAP and AHP technique, the key lean manufacturing improvement programs can be prioritised by using both qualitative and quantitative criteria. The analysis covers the planning stage of the KBCLMM. The utilisation of the approach is demonstrated with an illustrative example.
\end{abstract}

Keywords: Analytic Hierarchy Process (AHP), lean manufacturing, Knowledge-Based System (KBS), Gauging Absences of Pre-Requisites (GAP).

Streszczenie: Celem niniejszej pracy badawczej jest przedstawienie rozmaitych sposobów wyboru programów poprawy wydajności dla systemu Zespołowego Zarządzania Produkcją obniżającego nakłady (CLMM), opartego na Bazach Wiedzy. Omawiane sposoby, to Pomiar Niedostępności Warunków Wstępnych (Gauging Absences of Pre-Requisites GAP) oraz Analityczne Procesy Hierarchiczne (Analytic Hierarchy Process - AHP). W ramach prezentowanej pracy badawczej opracowano generyczny System Oparty na Bazie Wiedzy pozwalający na pomiar przydatności systemu CLMM w zakładzie produkcyjnym przemysłu samochodowego w porównaniu $\mathrm{z}$ systemem idealnym. Dzięki zastosowaniu wbudowanych technik GAP oraz AHP można optymalizować kluczowe programy zarządzania produkcją, określając priorytety za pomocą kryteriów ilościowych, jak i jakościowych. Analiza obejmuje również etap planowania systemu KBCLMM. Wykorzystanie każdego sposobu jest przedstawione za pomocą poglądowego przykładu.

Słowa kluczowe: Analityczny Proces Hierarchiczny (AHP), zarządzanie obniżające nakłady, Systemy Baz Wiedzy (KBS), Pomiar Niedostępności Warunków Wstępnych (Gauging Absences of Pre-Requisites - GAP) 


\section{Introduction}

Lean manufacturing is a management philosophy that focuses on producing the highest value product on time (Liker and $\mathrm{Yu}, 2000$ ). The highest value of products is achieved by identifying and eliminating wastes (all non-value-added activities) through continuous improvement which result in greater productivity, shorter delivery times, cost reduction, improved quality, increased customer satisfaction and higher profit (Schroer, 2004, Dolcemascolo, 2006).

A new concept called Collaborative Lean Manufacturing Management (CLMM) can be implemented for any car manufacturer to improve their lean manufacturing processes (Nawawi et al., 2007). In the CLMM chain, all members in the automotive manufacturing chain must work together towards common objectives in order to make lean manufacturing achievable in the collaborative environment.

This paper proposes the integration of a decision making tool, Analytic Hierarchy Process (AHP), with the hybrid Knowledge based (KB)/ Gauging Absences of PreRequisites (GAP). The detail of this hybrid system is described in the following sections.

\section{Hybrid Knowledge-Based System and GAP Analysis}

The planning stage is the basis for developing CLMM. In the planning stage there are two major sets of information that need to be considered: Collaborative Business and Lean Manufacturing perspectives as shown in Fig. 1.

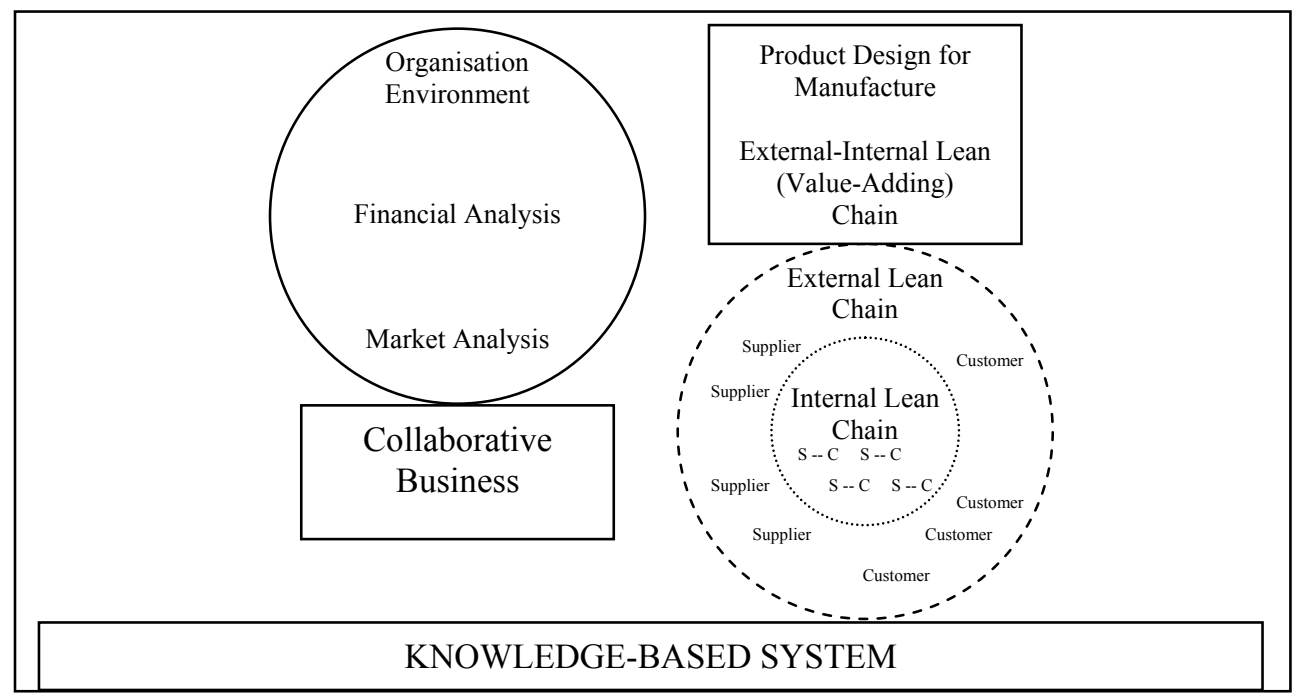

Fig. 1 Planning Stage of Conceptual Model for CLMM 
The function for the first part of Planning Stage, Collaborative Business is for gathering general information about the organisations environment, financial and market status. Organisation environment determines the particular environment the company is operating in. The information needed in this module are size of company, annual sales turnover, number of employees, age of company, position of company in automotive chain, competitors, suppliers, customers, and investment in CLMM activities. In CLMM, the position of a company in the supply chain is required to determine its suppliers and customers, since emphasis in not only within the organisation (internal), but also between organisations (external) (Womack and Jones, 2003).

In the second part of Planning Stage, Lean Manufacturing Chain component refers to connections between any two value-adding activities inside and across organisations. Activity in any process can be allocated as value-adding or nonvalue adding. In lean manufacturing, non-value adding activity is considered as a waste and must be eliminated. Lean Manufacturing Chain can be divided into three subcomponents, Internal Chain, External Chain, and Product Design for Manufacture. In the Internal Lean Chain, operators of the next process are the customers, and suppliers (current process) are committed to supply parts which are good in quality at the right time and right quantity. Customer satisfaction and supplier commitment are two major elements which contribute to the success of the internal lean chain. In the External Lean Chain, suppliers are considered as partners (Monden, 1998) instead of outsiders. Suppliers are well informed about the demand and planning of the organisation and sometimes invited to involve in the product development and process design. The Product Design for Manufacture is developed with objectives of gathering product design information and analysing the product design process which covers from the conceptual design to the full launch of new products.

The utilisation of a knowledge-based (KB) approach is a basis for CLMM system development. In this study, the production rule-based type of KBS is used to structure the knowledge and information that is gathered and compiled from literature and interactive session with users. By using selected KB shell software, all modules are developed independently and finally linked each other in the integrated KBCLMM system. The example of rule-base for Internal Lean Chain sub-module in the Lean Manufacturing Perspective module used for deducing this condition is listed as follows.

IF the organisation have kaizen team which regularly conduct kaizen event to improve the process (Yes: GP; No: BP, PC1)

AND the kaizen event is always documented (Yes: GP; No: BP, PC1)

AND the kaizen event is documented and presented to top management (Yes: GP; No: BP, PC1)

AND the kaizen event is always presented to staff of operations (Yes: GP; No: BP, PC1) 
AND the kaizen event is always presented to staff of planning (Yes: GP; No: BP, PC3)

AND the kaizen event is always presented to staff of purchasing (Yes: GP; No: BP, PC4)

AND the kaizen event is always presented to staff of financial (Yes: GP; No: BP, PC4)

AND the kaizen event is always presented to staff of administration (Yes: GP; No: BP, PC1)

AND the organisation implements cellular layout as part of internal continuous improvement (Yes: GP; No: BP, PC1)

AND the organisation implements pull production as part of internal continuous improvement (Yes: GP; No: BP, PC1)

AND the organisation implements Kanban control as part of internal continuous improvement (Yes: GP; No: BP, PC1)

AND the organisation implements set-up time reduction as part of internal continuous improvement (Yes: GP; No: BP, PC1)

THEN the organisation commitment to kaizen events and internal continuous improvement is good

OR the organisation needs to improve the kaizen event and internal continuous improvement activities

In this study, a technique known as Gauging Absences of Pre-requisites (GAP) analysis is used to assess the gap between the organisation's actual environment and an ideal one, resulting in knowledge of the desirable pre-requisites for an effective implementation (Udin, 2004).

Table 1. Problem Categories and Description of GAP Analysis Technique

\begin{tabular}{|c|c|}
\hline $\begin{array}{c}\text { Category } \\
\text { Code }\end{array}$ & Description \\
\hline PC1 & $\begin{array}{l}\text { This indicates a serious problem, which should be resolved immediately. If } \\
\text { resolved, it is quite likely to provide real benefits. }\end{array}$ \\
\hline PC2 & $\begin{array}{l}\text { This indicates a serious problem, which is likely to have pre-requisites and } \\
\text { is better dealt with as part of an appropriate and logical improvement and } \\
\text { implementation plan. }\end{array}$ \\
\hline PC3 & $\begin{array}{l}\text { This is not a serious problem and can be dealt with now. If resolved, it is } \\
\text { likely to produce short-term benefits. }\end{array}$ \\
\hline PC4 & $\begin{array}{l}\text { This is not a serious problem. Although it could be dealt with now, it is } \\
\text { unlikely to produce short-term benefits. Therefore, it should only be dealt } \\
\text { with if it is a pre-requisite for other things. }\end{array}$ \\
\hline PC5 & $\begin{array}{l}\text { This is not really a Good or Bad point itself. The questions associated with } \\
\text { this category are primarily asked to identify certain situations in the } \\
\text { environment, which depends on subsequent questions and hence may } \\
\text { reveal other problems. }\end{array}$ \\
\hline
\end{tabular}

An explanation facility is also provided in the system in order to assist the users in understanding the questions. Many of the questions are used with the GAP Analysis and are indicated by either Good Point (GP) code or Bad Point (BP) with problem categories code (PC1 to PC5). The description of the code is as described by (Udin, 2004) and as shown in Table 1. By answering the questions, the missing 
Knowledge-Based Collaborative Lean Manufacturing Management...

System zespołowego zarzadzania produkcja, obniżajacy nakłady...

pre-requisites of the manufacturer position in relative to the benchmark can be identified through the number of Bad Points and its PC number.

\section{AHP System in KBCLMM}

First developed and introduced by Saaty in 1970s (Saaty, 2001), AHP deals with complex, unstructured and multi-attribute decision problems. The application of AHP is widely accepted in various areas such as operation management, manufacturing, economics, business, and information technology (Render et al., 2006). With its ability to mimic human opinions in structuring a complex and multi-attribute problem, AHP has significantly improved the performance of the decision-making process in organisations. Razmi et. al. (2000) stress that the AHP is a powerful tool, which can be used to deal with multi-attribute and complex problems particularly in selecting and prioritising an alternative for improvement purposes. AHP has the capability to weight the alternatives and make a comparison amongst the alternatives before the optimum solution can be suggested. The AHP structure for Lean Manufacturing Perspective has been developed and is shown in Fig. 2.

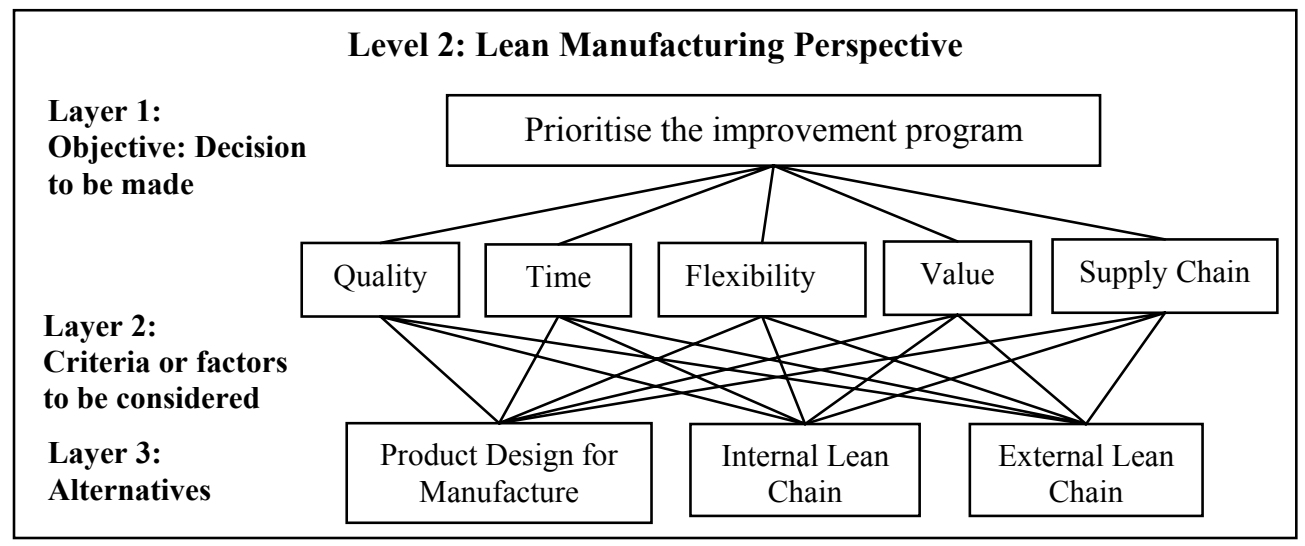

Fig. 2 The AHP Structure for Lean Manufacturing Perspective of KBCLMM

Layer 1 is the focus, which sets the objective of the structure, which is to prioritise and select the most needed improvement program for the Lean Manufacturing Perspective activities. Layer 2 of the hierarchy consists of Quality, Time, Flexibility, Value and Supply Chain which are the factors or criteria that influenced the selection of the improvement programs. Finally in Layer 3, there are alternatives that should be prioritised and improved within the organisation to reflect the readiness of the organisation to implement the improvement programs for Lean Manufacturing Perspective. This level consists of Product Design for Manufacture (PDfM), Internal Lean Chain (ILC), and External Lean Chain (ELC). 
The needs for these alternatives are assessed based on the criteria in Layer 2 through series of questions in KBCLMM and GAP analysis (Nawawi et al., 2008).

In this paper, only the Lean Manufacturing Perspective (LMP) and its three submodules (PDfM, ILC and ELC) will be illustrated in detail. The comparisons or pair-wise comparisons (term used in AHP analysis) start from this level. The data for these comparisons is transferred directly from the process of GAP analysis embedded in the KBCLMM Model.

For each of this sub-module, there are another two or three elements that can be taken to improve that particular CLMM activity. Fig. 3 shows the improvement initiative elements for PDfM sub-module. The elements are Conceptual Design, Design Tools for Analysis or Product Development.

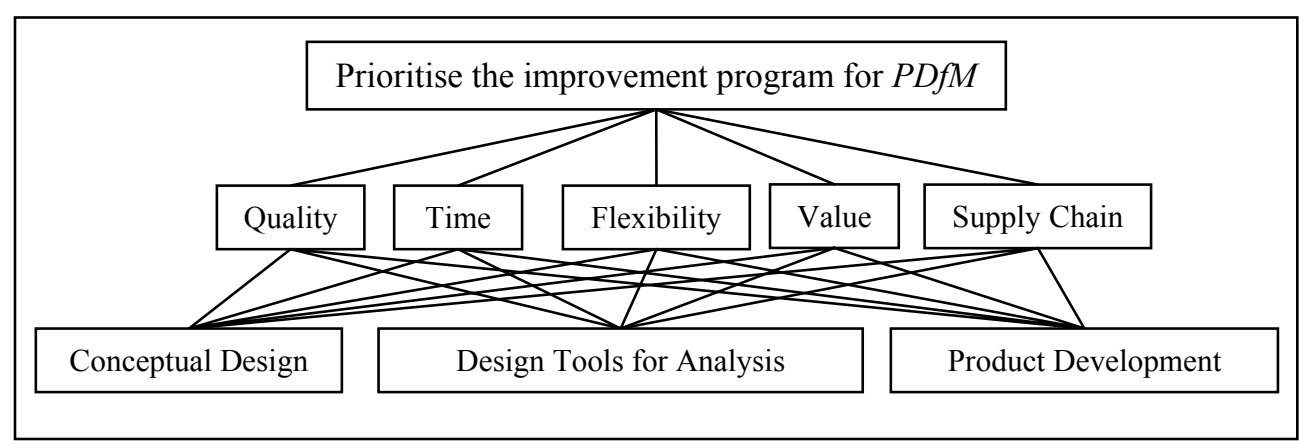

Fig. 3 The AHP Structure for PDfM sub-module of Lean Manufacturing Perspective

Based on GAP analysis in the first paper, for each of this sub-module, AHP decides which of these elements (Conceptual Design, Design Tools for Analysis or Product Development) should be in priority of improvement to increase company competitiveness for $P D F M$.

This is also the case for Internal Lean Chain (ILC) and External Lean Chain (ELC) sub-modules. Figures 4 and 5 show the improvement initiative elements for these sub-modules. As shown in Figure 4, AHP decides which of these elements (Internal Continuous Improvement or Internal Process Control) should be in priority of improvement to increase company competitiveness for ILC. For ELC, AHP decides which of these elements (Integration with Suppliers or Integration with Customers) should be in priority of improvement to increase company competitiveness as shown in Figure 5.

At the same time, the AHP Model also decides which one of these three factors (PDfM, ILC and ELC) should be in priority of improvement to increase company competitiveness for Lean Manufacturing Perspective. This module is designed in 
Knowledge-Based Collaborative Lean Manufacturing Management...

System zespotowego zarzadzania produkcja, obniżajacy nakłady...

order to determine the most suitable improvement priorities of company competitiveness for a given circumstance based on the interactive user's answers for each sub-module.

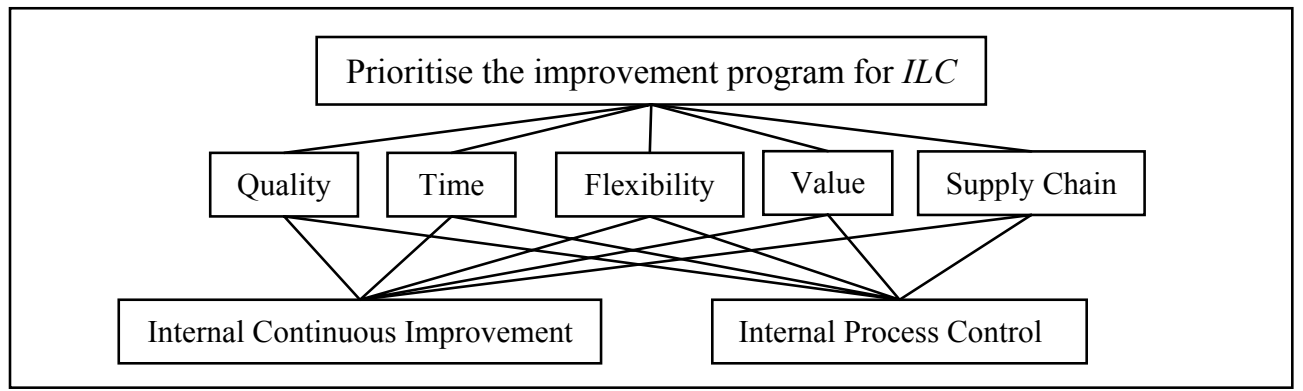

Fig. 4 The AHP Structure for ILC sub-module of Lean Manufacturing Perspective

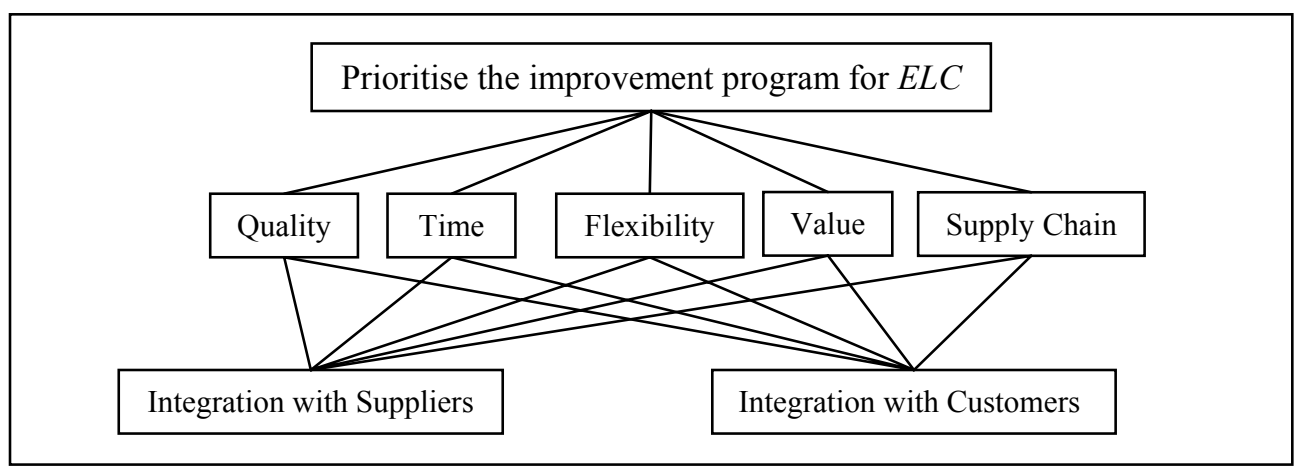

Fig. 5 The AHP Structure for ELC sub-module of Lean Manufacturing Perspective

The combination between the GAP Analysis and the AHP approach needs a transferred process of scale. It has been explained that in the GAP analysis there are five Problem Categories for each performance condition assessed, while the AHP approach provides nine Intensity of Importance to be implemented for the each sub-module level. The process is given in detail by (Wibisono, 2003) and (Udin, 2004).

\section{Results}

In order to evaluate the system performance and consistency, the KBCLMM model for the second part of the planning stage has been validated using industrial data. An automotive manufacturer in Malaysia is selected and interview was conducted with key personnel of the company for this purpose. The summarised results for each sub-module are shown in Table 2. 
Table 2. Summarised GAP Analysis Results of Lean Manufacturing Perspective

\begin{tabular}{|c|c|c|c|c|c|c|c|c|}
\hline \multirow{3}{*}{$\begin{array}{l}\text { Level 2: } \\
\text { Lean Manufacturing Perspective }\end{array}$} & \multirow{3}{*}{$\begin{array}{c}\text { No of } \\
\text { Questions }\end{array}$} & \multicolumn{7}{|c|}{ GAP Analysis } \\
\hline & & \multirow[t]{2}{*}{ GP } & \multirow[t]{2}{*}{$\mathrm{BP}$} & \multicolumn{5}{|c|}{$\begin{array}{l}\text { Problem } \\
\text { Category }\end{array}$} \\
\hline & & & & 1 & 2 & 3 & 4 & 5 \\
\hline \multicolumn{9}{|c|}{ Product Design for Manufacture (PDfM) } \\
\hline Conceptual Design & 49 & 42 & 7 & 0 & 0 & 0 & 7 & 0 \\
\hline Design Tools for Analysis & 19 & 19 & 0 & 0 & 0 & 0 & 0 & 0 \\
\hline Product Development & 16 & 14 & 2 & 2 & 0 & 0 & 0 & 0 \\
\hline Total & 84 & 75 & 9 & 2 & $\mathbf{0}$ & $\mathbf{0}$ & 7 & $\mathbf{0}$ \\
\hline \multicolumn{9}{|l|}{ Internal Lean Chain (ILC) } \\
\hline Internal Continuous Improvement & 31 & 28 & 3 & 1 & 0 & 0 & 2 & 0 \\
\hline Internal Process Control & 18 & 13 & 5 & 5 & 0 & 0 & 0 & 0 \\
\hline Total & 49 & 41 & 8 & 6 & $\mathbf{0}$ & $\mathbf{0}$ & 2 & $\mathbf{0}$ \\
\hline \multicolumn{9}{|l|}{ External Lean Chain (ELC) } \\
\hline Integration with Suppliers & 24 & 18 & 6 & 4 & 1 & 1 & 0 & 0 \\
\hline Integration with Customers & 8 & 6 & 2 & 1 & 0 & 0 & 0 & 1 \\
\hline Total & 32 & 24 & 8 & 5 & 1 & 1 & $\mathbf{0}$ & 1 \\
\hline Grand Total & 165 & 140 & 25 & 13 & 1 & 1 & 9 & 1 \\
\hline
\end{tabular}

Table 2 shows the summarised GAP Analysis Results of Lean Manufacturing Perspective. It contains the total number of 165 questions that have been asked, the number of Good Points (GP) and the number of Bad Points (BP), along with their Problem Categories. In the GAP Analysis, only BP are categorised into Problem Categories, with the aim of identifying the missing pre-requisites that are needed in order to implement CLMM successfully.

In the Product Design for Manufacture (PDfM) module, the KBCLMM has identified many problems at Conceptual Design with seven from nine Bad Points being exactly there. However, all the problems are not serious problems since all of them are under PC4 whereas for Product Development, there are two PC1. In the Internal Lean Chain (ILC) module, the System has found five PC1 at Internal Process Control, which indicates the area needs immediate improvement. In the External Lean Chain (ELC) module, the KBCLMM has discovered that the major problem area is at Integration with Suppliers with six Problem Categories (four PC1, one PC2, and one PC3) out of eight Bad Points.

Based on the results of the GAP analysis for Level 2, the KBCLMM model then processes the results using the AHP approach to determine which aspect should be in priority of improvement and how the weight of priority between PDfM, ILC and $E L C$ should be determined. Tables 1-3 depict the priority vector values for each of elements in each of the sub-modules, and Table 4 shows the priority vector values 
Knowledge-Based Collaborative Lean Manufacturing Management...

System zespolowego zarzadzania produkcja, obnizajacy naktady...

for $P D f M, I L C$ and $E L C$ based on the results of the GAP analysis.

Table 3. AHP Analysis with priority vector for $P D f M$ sub-module

\begin{tabular}{|c|c|c|c|c|}
\hline Aspect & $\begin{array}{c}\text { Conceptual } \\
\text { Design }\end{array}$ & $\begin{array}{c}\text { Design Tools } \\
\text { for Analysis }\end{array}$ & $\begin{array}{c}\text { Product } \\
\text { Development }\end{array}$ & $\begin{array}{c}\text { Priority } \\
\text { Vector }\end{array}$ \\
\hline $\begin{array}{c}\text { Conceptual } \\
\text { Design }\end{array}$ & 1 & 1 & $1 / 2$ & 0.2680 \\
\hline $\begin{array}{c}\text { Design Tools } \\
\text { for Analysis }\end{array}$ & 1 & 1 & $1 / 2$ & 0.1946 \\
\hline $\begin{array}{c}\text { Product } \\
\text { Development }\end{array}$ & 2 & 2 & 1 & $\mathbf{0 . 5 3 7 4}$ \\
\hline
\end{tabular}

Table 3 shows that the priority vector for Conceptual Design is 0.2680 , Design Tools for Analysis is 0.1946, and Product Development is 0.5374 . It means that based on the GAP analysis and AHP process embedded in the system, for PDfM, the company should place its improvement priority firstly on the Product Development.

Table 4. AHP Analysis with priority vector for $I L C$ sub-module

\begin{tabular}{|c|c|c|c|}
\hline Aspect & $\begin{array}{c}\text { Internal Continuous } \\
\text { Improvement }\end{array}$ & $\begin{array}{c}\text { Internal Process } \\
\text { Control }\end{array}$ & Priority Vector \\
\hline $\begin{array}{c}\text { Internal Continuous } \\
\text { Improvement }\end{array}$ & 1 & $1 / 3$ & 0.2500 \\
\hline $\begin{array}{c}\text { Internal Process } \\
\text { Control }\end{array}$ & 3 & 1 & $\mathbf{0 . 7 5 0 0}$ \\
\hline
\end{tabular}

Table 4 shows that the priority vector for Internal Continuous Improvement is 0.25 and for Internal Process Control is 0.75 . This means the company should place its improvement priority firstly on the Internal Process Control compared to Internal Continuous Improvement aspect.

Table 5. AHP Analysis with priority vector for $E L C$ sub-module

\begin{tabular}{|c|c|c|c|}
\hline Aspect & $\begin{array}{c}\text { Integration with } \\
\text { Suppliers }\end{array}$ & $\begin{array}{c}\text { Integration with } \\
\text { Customers }\end{array}$ & Priority Vector \\
\hline $\begin{array}{c}\text { Integration with } \\
\text { Suppliers }\end{array}$ & 1 & 2 & $\mathbf{0 . 6 6 6 7}$ \\
\hline $\begin{array}{c}\text { Integration with } \\
\text { Customers }\end{array}$ & $1 / 2$ & 1 & 0.3333 \\
\hline
\end{tabular}

Table 5 shows that the priority vector for Integration with Suppliers is 0.6667 and for Integration with Customers is 0.3333 . This means the company should place its improvement priority firstly on Integration with Suppliers compared to Integration with Customers.

Finally, the same AHP process is then carried out at a higher level for PDfM, ILC 
and $E L C$. Table 4 shows that the priority vector for $P D f M$ is 0.1638 , for $I L C$ is 0.2973 , and for $E L C$ is 0.5390 . Based on the GAP analysis and AHP process embedded in the system, the company should place its improvement priority firstly on ELC, then $I L C$ and lastly PDfM. The similar procedures of performance assessment are conducted for the other levels.

Table 6. AHP Analysis with priority vector for Lean Manufacturing Perspective of KBCLMM

\begin{tabular}{|c|c|c|c|c|}
\hline Aspect & $\begin{array}{c}\text { Product Design } \\
\text { for Manufacture } \\
\text { (PDfM) }\end{array}$ & $\begin{array}{c}\text { Internal } \\
\text { Lean Chain } \\
\text { (ILC) }\end{array}$ & $\begin{array}{c}\text { External } \\
\text { Lean Chain } \\
\text { (ELC) }\end{array}$ & $\begin{array}{c}\text { Priority } \\
\text { Vector }\end{array}$ \\
\hline $\begin{array}{c}\text { Product Design } \\
\text { for Manufacture } \\
\text { (PDfM) }\end{array}$ & 1 & $1 / 2$ & $1 / 3$ & 0.1638 \\
\hline $\begin{array}{c}\text { Internal Lean } \\
\text { Chain (ILC) }\end{array}$ & 2 & 1 & $1 / 2$ & 0.2973 \\
\hline $\begin{array}{c}\text { External Lean } \\
\text { Chain (ELC) }\end{array}$ & 3 & 2 & 1 & $\mathbf{0 . 5 3 9 0}$ \\
\hline
\end{tabular}

Based on the results from Tables 3-6, Table 7 provides the summary of the AHP Priority Vectors for each of the modules and sub-modules.

From Table 7, it can be seen that the KBCLMM System suggests that the company should focus firstly to improve the External Lean Chain (ELC) activity because of the highest Priority Vector of 0.5390 . In the ELC itself, the company should place its improvement priority on the Integration with Suppliers elements (with Priority Vector of 0.6667$)$.

Table 7. Summary of AHP Results for Lean Manufacturing Perspective of KBCLMM

Level 2: Lean Manufacturing Perspective

\begin{tabular}{|l|c|l|c|}
\hline \multicolumn{1}{|c|}{ Module } & $\begin{array}{c}\text { Priority } \\
\text { Vector }\end{array}$ & \multicolumn{1}{c|}{ Sub-module } & Priority Vector \\
\hline \multirow{2}{*}{$\begin{array}{l}\text { Product Design for } \\
\text { Manufacture (PDfM) }\end{array}$} & \multirow{2}{*}{0.1638} & Conceptual Design & 0.2680 \\
\cline { 3 - 4 } & & Design Tools for Analysis & 0.1946 \\
\cline { 3 - 4 } $\begin{array}{l}\text { Internal Lean Chain } \\
\text { (ILC) }\end{array}$ & \multirow{2}{*}{0.2973} & $\begin{array}{l}\text { Internal Development } \\
\text { Improvement }\end{array}$ & $\mathbf{0 . 5 3 7 4}$ \\
\cline { 3 - 4 } & & Internal Process Control & 0.2500 \\
\hline $\begin{array}{l}\text { External Lean Chain } \\
\text { (ELC) }\end{array}$ & \multirow{2}{0.5390}{} & Integration with Suppliers & $\mathbf{0 . 7 5 0 0}$ \\
\cline { 3 - 4 } & Integration with Customers & 0.3333 \\
\hline
\end{tabular}

It can also be seen in Table 7 that the following suggestions by the KBCLMM System. The company then should focus to improve Internal Lean Chain (ILC) activity (with Priority Vector of 0.2973 ) before committing the improvement 
program for Product Design for Manufacture (PDfM) activity (with Priority Vector of 0.1638). In the ILC activity, the company needs to focus more on Internal Process Control aspect (with Priority Vector of 0.75) compared to Internal Continuous Improvement aspect (with Priority Vector of 0.25). Lastly, in the PDfM activity, the company needs to focus more on Product Development aspect (with Priority Vector of 0.5374) compared to both Conceptual Design (with Priority Vector of 0.2680) and Design Tools for Analysis aspects (with Priority Vectors of 0.1946).

\section{Conclusion}

This paper has described an application of hybrid (KB, GAP, and AHP approach) methodology to improve the collaborative lean manufacturing activities. The AHP structure for Lean Manufacturing Perspective of KBCLMM model consisting of three layers was developed to serve the purpose. There are alternatives of improvement programs identified i.e. Product Design for Manufacture (PDfM), Internal Lean Chain (ILC), and External Lean Chain (ELC). For each of these alternatives, there are two or three sub alternatives that need to be prioritised for that particular improvement alternative. In the examples based on the industrial information given for Lean Manufacturing Perspective module, the company should focus more to improve the PDfM activity, and in the PDfM activity itself, the company should place its improvement priority firstly on the Conceptual Design and Product Development elements. By incorporating the GAP and AHP analysis technique, the KBCLMM system assists users to easily understand the position of their organisation and what programs should be taken first to optimise the improvement process.

\section{References}

1. DOLCEMASCOLO, D. (2006) Improving The Extended Value Stream: Lean For The Entire Supply Chain, New York, Productivity Press.

2. LIKER, J. K. \& YU, Y.-C. (2000) Japanese Automakers, U.S. Suppliers and Supply-Chain Superiority. MIT Sloan Management Review, 42, 81-89.

3. MONDEN, Y. (1998) Toyota Production System: An Integrated Approach to Just-In-Time, Norcross, Georgia, Engineering \& Management Press.

4. NAWAWI, M. K. M., KHAN, M. \& HUSSAIN, K. (2007) Conceptual Model of Collaborative Lean Manufacturing Management System: Planning Stage. The 5th International Conference on Manufacturing Research (ICMR07). De Montfort University, UK. 
5. NAWAWI, M. K. M., KHAN, M. K. \& HUSSAIN, K. (2008) Paper 1: Colllaborative Lean Manufacturing Management - The Framework and Hybrid Knowledge-Based System. 24th International Conference on CARS \& FOF'08.

6. RAZMI, J., RAHNEJAT, H. \& KHAN, M. K. (2000) The new concept of manufacturing "DNA" within an analytic hierarchy process-driven expert system. European Journal of Innovation Management, 3, 199.

7. RENDER, B., RALPH M. STAIR, J. \& HANNA, M. E. (2006) Quantitative Analysis for Management, Upper Saddle River, New Jersey, Pearson Prentice Hall.

8. SAATY, T. L. (2001) Decision making for leaders: the analytical hierarchy process for decisions in a complex world, Pittsburgh, RWM Publications.

9. SCHROER, B. J. (2004) Simulation as a Tool in Understanding the Concepts of Lean Manufacturing. SIMULATION, 80, 171-175.

10.UDIN, Z. M. (2004) A hybrid knowledge-based approach for planning and designing a collaborative supply chain management system. School of Engineering, Design and Technology. Bradford, UK, University of Bradford.

11.WIBISONO, D. (2003) A knowledge based approach to assist in the design of a performance measurement system for a manufacturing environment. School of Engineering, Design and Technology. Bradford, UK, University of Bradford.

12.WOMACK, J. P. \& JONES, D. T. (2003) Lean thinking: banish waste and create wealth in your corporation: revised and updated, New York, Simon and Schuster.

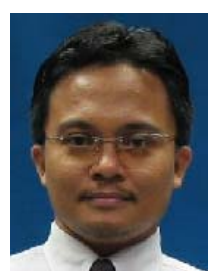

Mohd Kamal Mohd Nawawi, an academic staff from Universiti Utara Malaysia, currently pursuing his $\mathrm{PhD}$ at University of Bradford, UK.

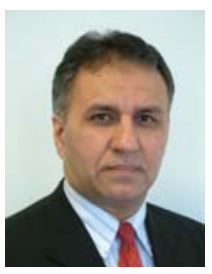

Dr. M. K. Khan is the Associate Dean - International Programmes at the School of Engineering, Design \& Technology, University of Bradford, UK.

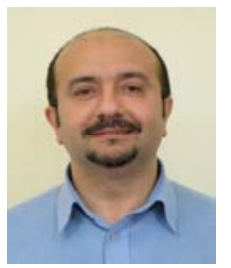

Dr. K. Hussain is the Director of Studies for Mechanical \& Automotive Engineering Courses at the School of Engineering, Design \& Technology, University of Bradford, UK. 